\title{
Activin A upregulates PTGS2 expression and increases PGE2 production in human granulosa-lutein cells
}

\author{
Pang-Pin Liu ${ }^{1,2}$, Hsun-Ming Chang ${ }^{1}$, Jung-Chien Cheng ${ }^{1}$ and Peter C K Leung ${ }^{1}$ \\ ${ }^{1}$ Department of Obstetrics and Gynaecology, Child and Family Research Institute, University of British Columbia, \\ Vancouver, British Columbia, Canada and ' Department of Obstetrics and Gynaecology, E-DA Hospital, \\ Kaohsiung, Taiwan
}

Correspondence should be addressed to P C K Leung; Email: peter.leung@ubc.ca

\begin{abstract}
Activin $\mathrm{A}$ is one of the members of transforming growth factor- $\beta$ superfamily that is expressed in human large luteal cells, and may act in an autocrine/paracrine manner to regulate luteal function. Prostaglandin-endoperoxide synthase 2 (PTGS2) enzyme and its derivative, prostaglandin E2 (PGE2), play significant roles in the regulation of corpus luteum formation and maintenance. To date, whether activin A can induce the expression of PTGS2 and the production of PGE2 in human granulosa-lutein cells is largely unknown. The aim of this study was to examine the effects of activin A on the regulation of PTGS2 expression and PGE2 production in human granulosa-lutein cells, and to investigate the underlying signal transduction mechanisms. In this study, the immortalized (SVOG cells) and primary human granulosa-lutein cells were used as the cell models. A TGF-p/activin type I receptor inhibitor, SB431542 and small interfering RNAs were used to investigate the activin A-induced downstream signaling pathway. We have demonstrated that activin A upregulated the expression of PTGS2 and increased the production of PGE2 via an ACVR1B-mediated SMAD2/3-SMAD4 signaling pathway. Our results suggest that activin A may be involved in the modulation of human corpus luteum formation via the induction of PTGS2 expression and PGE2 production.

Reproduction (2016) 152 655-664
\end{abstract}

\section{Introduction}

After ovulation, the corpus luteum that is developed from the granulosa and theca cells of the residual follicle plays an essential role in the establishment of embryo implantation and pregnancy (Niswender et al. 2000). In most mammals, the cyclic change of corpus luteum is featured by luteal development, maintenance and regression modulated by the interactions of several luteotrophic and luteolytic mediators (Arosh et al. 2004, Devoto et al. 2009). Among these mediators, prostaglandin (PG) E2 is considered as a luteotropin, whereas PGF2 $\alpha$ is a luteolysin (Horton \& Poyser 1976). In a variety of species, PGE2 has been shown to act as a luteoprotective or luteotropic factor during the luteal phase (Magness et al. 1981). In ruminants, administration of PGE2 protects the corpus luteum function from induced or spontaneous luteolysis (Henderson et al. 1977). In domestic animals, exogenous PGE2 prevents spontaneous or induced luteolysis and maintains luteal function during early pregnancy (Pate 2003, Weems et al. 2013, 2014). Similar anti-luteolytic or luteotropic effects of PGE2 have been shown in primates (ZelinskiWooten \& Stouffer 1990, Bogan et al. 2008). In humans, PGE2 can stimulate the CAMP-mediated progesterone secretion in the luteal phase (Marsh \& LeMaire 1974, Hahlin et al. 1988, Wang et al. 2012). In ewes, administration of PGE2 antagonist indomethacin inhibits luteal PGE2 production and progesterone secretion (Kim et al. 2001). Furthermore, there is a positive correlation between the expression of PGE2 and progesterone in the human luteal tissue (Vijayakumar \& Walters 1983). A clinical study has confirmed the contraceptive effect of a prostaglandin inhibitor due to its disruption on the luteal progesterone levels (Edelman et al. 2010). Collectively, all these studies indicate a critical role of PGE2 in the development and maintenance of a normal corpus luteum.

Prostaglandin-endoperoxide synthase (PTGS), also known as cyclooxygenase (COX), is the key enzyme responsible for the rate-limiting step of prostaglandin biosynthesis that has been recognized as the primary mediator of luteal function (Arosh et al. 2004). PTGS1 (COX-1) and PTGS2 (COX-2) are well-characterized PTGS enzymes that have similar activities (Sirois et al. 2004). PTGS1 is constitutively expressed in most cells and is involved in the production of prostaglandins in relation to various homeostatic functions. Under normal physiological conditions, PTGS2 is undetectable in most 
tissues but can be induced by various inflammatory, carcinogenic and pathological processes (Stouffer et al. 2007, Liu et al. 2015). Studies have shown that the PG components, including PTGS1, PTGS2, PGE2 and PGE2 signaling (PGE2 receptor 3 ) are highly expressed in the large luteal cells of primate corpus luteum, indicating that the PGE2 biosynthesis and bioactivity are selectively activated during the luteal development and maintenance (Arosh et al. 2004, Bogan et al. 2008). Notably, gene targeting studies have shown that PTGS2 is one of the important mediators of corpus luteum formation, implantation, decidualization and early pregnancy (Lim et al. 1999, Reese et al. 2001).

Activins belong to the transforming growth factor- $\beta$ (TGF- $\beta$ ) superfamily and are widely expressed in many tissues, where they regulate a variety of physiological processes, including reproduction (Knight \& Glister 2001, 2006). In the ovaries, activin A is expressed in granulosa cells and may act in an autocrine/paracrine manner to regulate ovarian function, including steroidogenesis, granulosa cell proliferation, follicular development, oocyte maturation and corpus luteum function (Findlay 1993, Knight \& Glister 2001). In rodents, the LH surge significantly downregulates the expression of INHA (inhibin $\alpha$ ) and INHBA (inhibin $\beta A$, the precursor monomer of active $A$ ) which leads to little activin or inhibin production or secretion by the corpus luteum (Woodruff et al. 1988). However, in some ruminants and primate ovaries, inhibin $\beta A$, activin receptors and its binding protein follistatin are all expressed in the corpus luteum (Fraser et al. 1993, Silva et al. 2004). In the human corpus luteum, inhibin $\beta A$ and follistatin mRNA and protein are expressed in the luteinized granulosa cells (large luteal cells), but not in the luteinized theca cells (small luteal cells), indicating a potential role of activin-follistatin system in the regulation of human luteal activity (Eramaa et al. 1993, Roberts et al. 1993). In view of the critical roles of PTGS2 and PGE2 in the corpus luteum formation and the subsequent implantation and early pregnancy, the regulation of PTGS2 expression and PGE2 production has been an area of interest for research. It has been reported that TGF- $\beta 1$ and nitric oxide are able to induce the expression of PTGS2 and the synthesis of PGE2 in human granulosa-lutein cells (Fang et al. 2014, 2015). To date, whether activin A can induce the expression of PTGS2 and PGE2 production in human granulosa-lutein cells remains to be elucidated. Given that activin A, PTGS2 and PGE2 are all essential factors for corpus luteum function, we hypothesized that activin A may regulate the expression of PTGS2 and the production of PGE2 in human granulosa-lutein cells to support the normal luteal function in the human ovary.

\section{Materials and methods}

\section{Preparation and culture of primary human granulosa-lutein (hGL) cells}

Primary hGL cells were obtained from patients who had provided informed consent after approval from the University of British Columbia Research Ethics Board. The controlled ovarian stimulation protocol for IVF patients consisted of the downregulation of either the luteal phase with nafarelin acetate (Synarel, Pfizer) or of the follicular phase with a GnRH antagonist (Ganirelix; Merck, Frosst). Gonadotropin stimulation with human menopausal gonadotropin (hMG; Menopur, Ferring) and recombinant FSH (Puregon, Merck) began on day 2 of the menstrual cycle and was followed by hCG (Pregnyl, Merck) administration 34-36 h before oocyte retrieval, based on follicle size. The collected hGL cells were purified via density centrifugation from the follicular aspirates collected from women undergoing oocyte retrieval as described previously (Chang et al. 2014a, 2016a). Individual primary cell cultures were composed of cells from one individual patient. Purified hGL cells were seeded $\left(2 \times 10^{5}\right.$ cells/well in 12 well plates) and cultured at $37^{\circ} \mathrm{C}$ in a humidified atmosphere with $5 \%$ $\mathrm{CO}_{2}$ in $95 \%$ air in Dulbecco's Modified Eagle Medium/ nutrient mixture F-12 Ham (DMEM/F-12; Sigma-Aldrich Corp) supplemented with $10 \%$ charcoal/dextran-treated fetal bovine serum (Hyclone, Logan, UT, USA), $100 \mathrm{U} / \mathrm{mL}$ penicillin (Life Technologies, Inc/BRL), $100 \mu \mathrm{g} / \mathrm{mL}$ streptomycin sulfate (Life Technologies, Inc/BRL), and $1 \times$ GlutaMAX (Invitrogen, Life Technologies). The culture medium was changed every other day in all experiments. Before being treated with growth factors, hGL cells were cultured in serum-free medium for $24 \mathrm{~h}$.

\section{Simian virus 40 large $T$ antigen-immortalized human granulosa cell (SVOG) culture}

A non-tumorigenic immortalized hGL cell line, SVOG, which was previously produced by the Simian virus 40 large $\mathrm{T}$ antigen transfection of early luteal phase human granulosa cells obtained from patients undergoing IVF (Lie et al. 1996), was used in this study. Because the immortalized SVOG cells were generated from primary hGL cells, they display biological responses to many different treatments that are similar to the responses of hGL cells (Chang et al. 2014b, 2015a,c, 2016b, Chen et al. 2015). SVOG cells were counted with a hemocytometer, and cell viability was assessed by $0.04 \%$ Trypan blue exclusion. The cells were seeded ( $2-4 \times 10^{5}$ cells/ $\mathrm{mL}$ in 6-well plates) and cultured in DMEM/F-12 medium supplemented with $10 \%$ charcoal/dextran-treated fetal bovine serum, $100 \mathrm{U} / \mathrm{mL}$ penicillin, $100 \mu \mathrm{g} / \mathrm{mL}$ streptomycin sulfate and $1 \times$ GlutaMAX. The cultures were maintained at $37^{\circ} \mathrm{C}$ in a humidified atmosphere containing $5 \% \mathrm{CO}_{2}$ and 95\% air. The culture medium was changed every other day in all experiments. Before being treated with growth factors, SVOG cells were cultured in serum-free medium for $24 \mathrm{~h}$. 


\section{Antibodies and reagents}

Recombinant human activin A was obtained from R\&D Systems and was composed of a Chinese hamster ovary cell-derived recombinant human protein that was $>95 \%$ pure based on sodium dodecyl sulfate polyacrylamide gel electrophoresis (SDS-PAGE) with silver staining. It was supplied in a lyophilized form from a $0.2 \mu \mathrm{m}$ filtered solution of $4 \mathrm{mM} \mathrm{HCL}$ with $0.1 \%$ BSA as a carrier protein. The TGF- $\beta$ type I receptor inhibitor SB431542 and PI3K inhibitor LY290042 were purchased from Sigma-Aldrich. The MAPK (ERK1/MEK2) inhibitor U0126 was obtained from Calbiochem. The polyclonal anti-PTGS2 antibody was obtained from Abcam. Rabbit anti-PTGS1 and goat anti-actin antibodies were obtained from Santa Cruz Biotechnology. Monoclonal mouse anti-phospho-ERK1/2 and polyclonal rabbit anti-phospho-Akt, anti-ERK1/2, antiAkt, anti-phospho-c-jun, anti-c-jun, anti-phospho-SMAD2, anti-phospho-SMAD3, anti-SMAD3, and anti-SMAD4 and monoclonal mouse anti-SMAD2 antibodies were obtained from Cell Signaling Technology. Horseradish peroxidaseconjugated goat anti-rabbit and goat anti-mouse IgGs were obtained from Bio-Rad Laboratories. Horseradish peroxidaseconjugated donkey anti-goat IgG was obtained from Santa Cruz Biotechnology.

\section{Reverse transcription quantitative real-time PCR (RT-qPCR)}

Total RNA was extracted using TRIzol reagent (Invitrogen, Life Technologies) according to the manufacturer's instructions. Reverse transcription into first-strand cDNA was performed with $2 \mu \mathrm{g}$ RNA, random primers, and Moloney murine leukemia virus (MMLV) reverse transcriptase (Promega). Each $20 \mu \mathrm{L}$ qPCR reaction contained $1 \times$ SYBR Green PCR Master Mix (Applied Biosystems), $20 \mathrm{ng}$ CDNA and 250 nM of each specific primer. The following primers were used: PTGS2, 5'CCC TTG GGT GTC AAA GGT AA-3' (sense) and 5'-GCC CTC GCT TAT GAT CTG TC-3' (antisense); PTGS1, 5'-TGC CCA GCT CCT GGC CCG CCG CTT-3' (sense); 5'-GTG CAT CAA CAC AGG CGC CTC TTC-3' (antisense); SMAD2, 5'-GCC TTT ACA GCT TCT CTG AAC AA-3' (sense) and 5'-ATG TGG CAA TCC TTT TCG AT-3' (antisense); SMAD3, 5'-CCC CAG CAC ATA ATA ACT TGG-3' (sense) and 5'-AGG AGA TGG AGC ACC AGA AG-3' (antisense); SMAD4, 5'-TGG CCC AGG ATC AGT AGG T-3' (sense) and 5'-CAT CAA CAC CAA TTC CAG CA-3' (antisense); and glyceraldehyde-3-phosphate dehydrogenase $(G A P D H)$, 5'-GAG TCA ACG GAT TTG GTC GT-3' (sense) and 5'-GAC AAG CTT CCC GTT CTC AG-3' (antisense). The mRNA levels of activin receptor type I (ACVR1) and activin receptor type IB $(A C V R 1 B)$ (also known as activin receptorlike kinase (ALK)2 and ALK4) were examined using TaqMan gene expression assays (Applied Biosystems). RT-qPCR was performed using an Applied Biosystems 7300 real-time PCR system equipped with a 96-well optical reaction plate. The specificity of each assay was validated based on a dissociation curve analysis and agarose gel electrophoresis of the PCR products. Three independent experiments were performed on different cultures, and each sample of the RT-qPCR experiment was assayed in triplicate. The mRNA levels were determined by taking the mean value of the triplicate measurements.
Relative quantification of the mRNA levels was performed using the comparative cycle threshold $(\mathrm{Ct})$ method and the $2^{-\triangle \Delta C t}$ formula, with GAPDH as the reference gene.

\section{Western blot analysis}

After treatment, cells were lysed in a lysis buffer $(20 \mathrm{mM}$ Tris, $150 \mathrm{mM} \mathrm{NaCl}, 1 \mathrm{mM} \mathrm{Na}{ }_{2}$ EDTA, $1 \mathrm{mM}$ EGTA, $1 \%$ Triton, $2.5 \mathrm{mM}$ sodium pyrophosphate, $1 \mathrm{mM} \beta$-glycerophosphate, $1 \mathrm{mM} \mathrm{Na} \mathrm{VO}_{4}, 1 \mu \mathrm{M}$ aprotinin, $1 \mu \mathrm{M}$ leupeptin and $1 \mathrm{mM}$ PMSF) (Cell Signaling Technology) containing a protease inhibitor cocktail (Sigma-Aldrich). Extracts were centrifuged at $20,000 \mathrm{~g}$ for $15 \mathrm{~min}$ at $4^{\circ} \mathrm{C}$ to remove cellular debris, and protein concentrations were quantified using the DC Protein

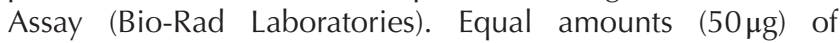
protein were separated via 10\% SDS-PAGE and transferred onto polyvinylidene fluoride membranes. The membranes were blocked with 5\% nonfat dry milk in Tris-buffered saline containing $0.05 \%$ Tween 20 for $1 \mathrm{~h}$ and incubated overnight at $4^{\circ} \mathrm{C}$ with primary antibodies. After washing the membranes with $1 \times$ Tris-buffered saline, the membranes were incubated with the appropriate horseradish peroxidase-conjugated secondary antibody for $1 \mathrm{~h}$. Immunoreactive bands were detected via an enhanced chemiluminescent substrate or a SuperSignal West Femto Chemiluminescence Substrate (Pierce). Membranes were stripped with stripping buffer (50 mM Tris- $\mathrm{HCl}(\mathrm{pH} 7.6)$, $10 \mathrm{mmol} / \mathrm{L} \beta$-mercaptoethanol and $1 \% \mathrm{SDS}$ ) at $50^{\circ} \mathrm{C}$ for $30 \mathrm{~min}$ and re-probed with anti-SMAD2 or anti-SMAD3.

\section{Small interfering RNA (siRNA) transfection}

To knock down endogenous ACVR1, ACVR1B, SMAD2, $S M A D 3$ or SMAD4 expression, cells were transfected with $25 \mathrm{nM}$ ON-TARGET plus SMART pool siRNA targeting specific genes, ACVR1 (L-004924-00-0005), ACVR1B (L-004925-000005), SMAD2 (L-003561-00-0005), SMAD3 (L-002006700-0005) or SMAD4 (L-003902-00-0005) (Dharmacon Technologies, Thermo Fisher Scientific) using Lipofectamine RNAiMAX (Invitrogen, Life Technologies). siCONTROL NonTargeting pool siRNA (D-001810-10-20) (Dharmacon) was used as the transfection control. The knockdown efficiency was confirmed via RT-PCR or western blot analysis.

\section{PGE2 enzyme-linked immunosorbent assay (ELISA)}

A human PGE2-specific ELISA was performed in accordance with the manufacturer's instructions (Cayman Chemical). SVOG cells were cultured in a six well plate with $2 \mathrm{~mL}$ DMEM/F-12 medium. After the treatments has been applied, the culture media and cell lysates were collected, and the concentrations of PGE2 in the culture media were measured using an ELISA and were normalized to the protein concentrations in the cell lysate. The normalized PGE2 values are presented as values relative to those of the control group.

\section{Statistical analysis}

The results are presented as the mean \pm S.E.M. of at least three independent experiments. Multiple comparisons were 
analyzed via one-way analysis of variance followed by Tukey's multiple comparison tests using PRISM software (GraphPad Software). Statistical significance was defined as $P<0.05$.

\section{Results}

\section{Activin A upregulates the expression of PTGS2 but not PTGS1 in hGL cells}

To investigate the effect of activin A on the expression of PTGS2 in hGL cells, we treated SVOG cells with different concentrations (1, 10 or $100 \mathrm{ng} / \mathrm{mL})$ of recombinant human activin $A$ (activin $A$ ). The results in
A

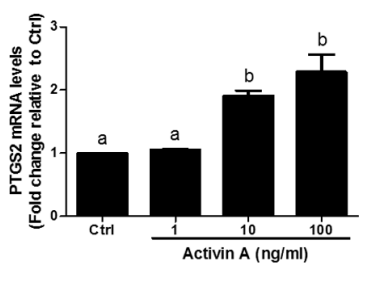

C

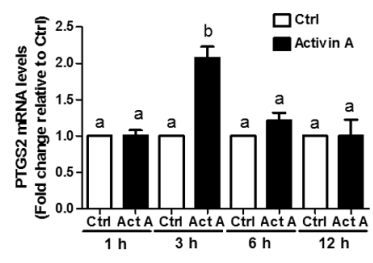

E hGL

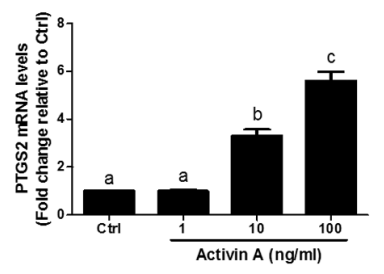

B

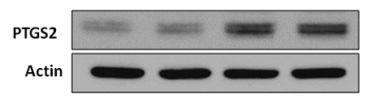

A

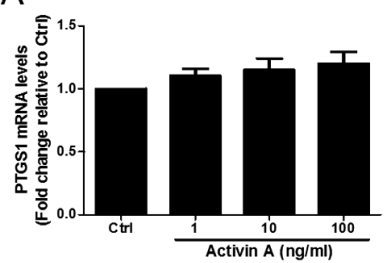

C

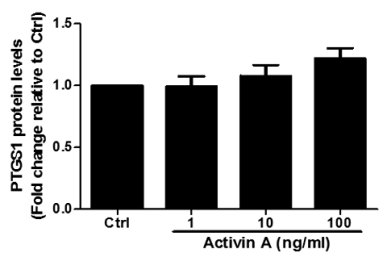

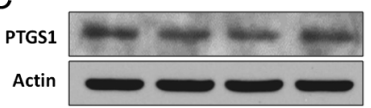

B

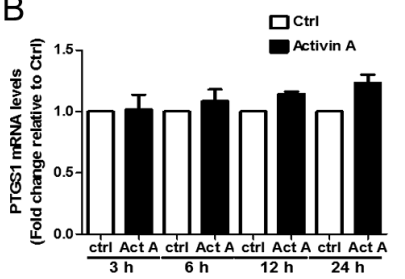

D
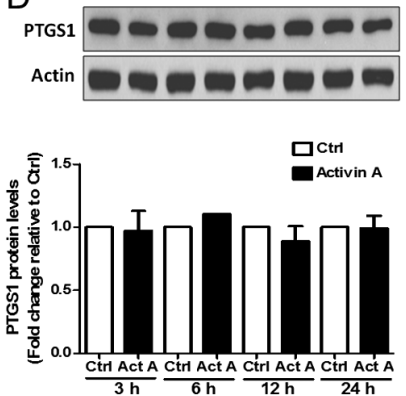

Figure 2 Activin A does not alter the expression of PTGS1 in SVOG cells. (A and C) SVOG cells were treated with vehicle control or different concentrations $(1,10$ or $100 \mathrm{ng} / \mathrm{mL})$ of activin $\mathrm{A}$, and the levels of PTGS1 mRNA (A) and protein (C) were examined via RT-qPCR and western blot analysis, respectively. (B and D) SVOG cells were treated with $30 \mathrm{ng} / \mathrm{mL}$ activin A for $3,6,12$ or $24 \mathrm{~h}$, and the levels of PTGS1 mRNA (B) and protein (D) were examined via RT-qPCR and western blot analysis, respectively. The results are expressed as the mean \pm S.E.M. of at least three independent experiments. Ctrl, control.

Fig. 1 reveal that treatment with activin A for 3 and $6 \mathrm{~h}$ significantly increased the PTGS2 mRNA (Fig. 1A) and protein (Fig. 1B) levels in a concentration-dependent manner. In addition, the treatment of SVOG cells with $30 \mathrm{ng} / \mathrm{mL}$ of activin $\mathrm{A}$ induced an increase in PTGS2 mRNA, with the maximal effect observed $3 \mathrm{~h}$ after treatment, and the mRNA levels declined thereafter (Fig. 1C). PTGS2 protein expression was increased at 6 and $12 \mathrm{~h}$ after treatment (Fig. 1D). Next, we used primary hGL cells obtained from IVF patients to further confirm the regulatory effects of activin A on PTGS2 expression. As shown in Fig. $1 \mathrm{E}$ and $\mathrm{F}$, activin $\mathrm{A}$ treatment increased PTGS2 mRNA and protein levels in a concentration-dependent manner in primary hGL cells. Because PTGS1 and PTGS2 enzymes have similar activities in many cellular functions, we next investigated the effect of activin $A$ on the expression of PTGS1 in SVOG cells. As shown in Fig. 2, treatment with activin A did not alter PTGS1 mRNA (Fig. 2A and B) or protein levels (Fig. 2C and D) at the different concentrations or time points examined.

\section{Activin A does not induce the phosphorylation of ERK1/2, PI3K/Akt and c-jun signaling in SVOG cells}

Apart from the SMAD-dependent signaling pathway, convincing evidence has indicated that the TGF- $\beta$ superfamily members can activate SMAD-independent 


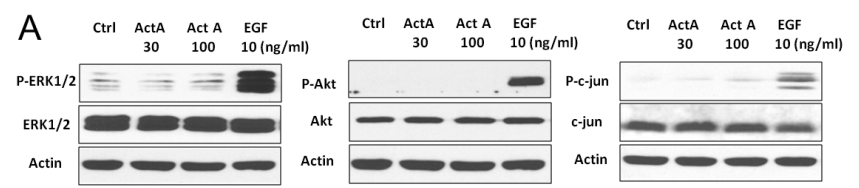

B
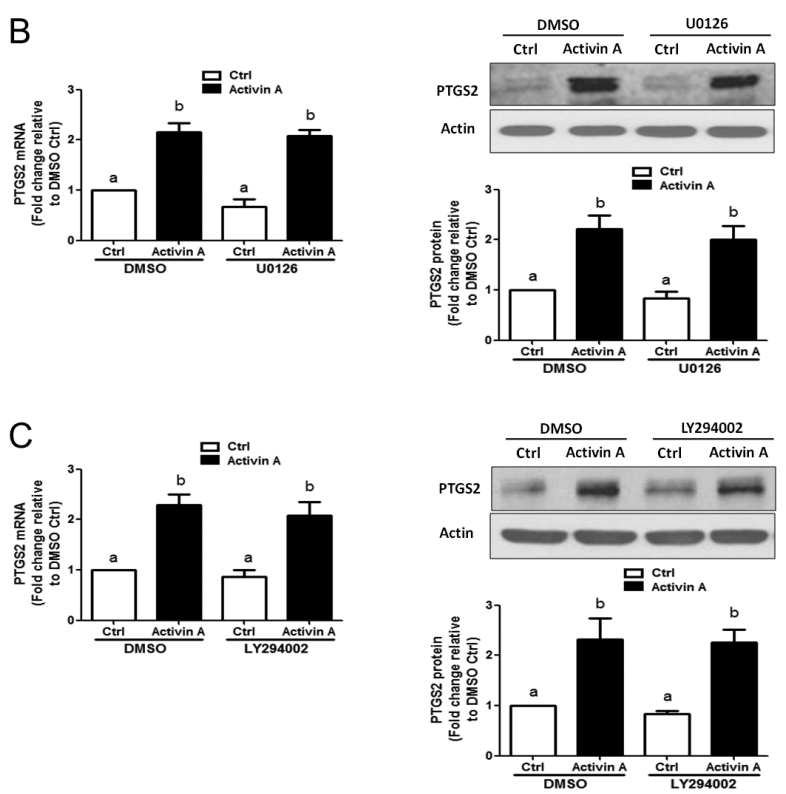

Figure 3 MAPK signaling pathways do not involve the activin A-induced upregulation of PTGS2 expression in SVOG cells. (A) SVOG cells were treated with vehicle control, 30 or $100 \mathrm{ng} / \mathrm{mL}$ of activin A or $10 \mathrm{ng} / \mathrm{mL}$ of EGF for $15 \mathrm{~min}$, and the levels of phosphoERK1/2, phospho-PI3K/Akt or phospho-c-jun were examined via western blot analysis. (B) SVOG cells were treated with $30 \mathrm{ng} / \mathrm{mL}$ of activin $\mathrm{A}$ for $3 \mathrm{~h}$ or $6 \mathrm{~h}$ in the absence (DMSO) or presence of $10 \mu \mathrm{M}$ U0126 and the levels of PTGS2 mRNA ( $3 \mathrm{~h}$ ) and protein (6h) were examined via RT-qPCR and western blot analysis, respectively. (C) SVOG cells were treated with $30 \mathrm{ng} / \mathrm{mL}$ of activin A for $3 \mathrm{~h}$ or $6 \mathrm{~h}$ in the absence (DMSO) or presence of $10 \mu \mathrm{M}$ LY294002 and the levels of PTGS2 mRNA ( $3 \mathrm{~h}$ ) and protein $(6 \mathrm{~h})$ were examined via RT-qPCR and western blot analysis, respectively. The results are expressed as the mean \pm S.E.M. of at least three independent experiments. Values marked with different letters are significantly different $(P<0.05)$. Act $\mathrm{A}$, activin $\mathrm{A}$; $\mathrm{Ctrl}$, control; MAPK, mitogenactivated protein kinase; PI3K, phosphoinositide 3-kinase.

signaling pathway (Derynck \& Zhang 2003). We sought to investigate whether activin A can act through several intracellular signal transduction pathways, such as mitogen-activated protein kinase (MAPK) pathways in SVOG cells. In contrast to the effects of epidermal growth factor (EGF, $10 \mathrm{ng} / \mathrm{mL}$ for $15 \mathrm{~min}$ ), an activator of MAPK pathways, activin A ( 30 or $100 \mathrm{ng} / \mathrm{mL}$ ) did not alter the phosphorylated levels of ERK1/2, phosphoinositide 3-kinase (PI3K)/Akt and c-jun (Fig. 3A).

\section{MAPK pathways do not involve in the activin A-induced upregulation of PTGS2 expression in SVOG cells}

To further determine the involvement of ERK1/2 or PI3K/ Akt signaling in the activin A-induced upregulation of
PTGS2 expression, an ERK1/2 inhibitor U0126 was used. As shown in Fig. 3B, pre-treatment of U0126 did not alter the activin A-induced increases in PTGS2 mRNA and protein levels in SVOG cells. Likewise, pretreatment of a PI3K/Akt inhibitor LY294002 did not affect the A-induced increases in PTGS2 mRNA and protein levels in SVOG cells (Fig. 3C).

\section{Activin A induces the phosphorylation of SMAD2/3 proteins in SVOG cells}

To investigate the underlying mechanism by which activin A regulates the expression of PTGS2, we used western blot analysis to examine the levels of phosphorylated SMAD2/3 after exposure to activin A in SVOG cells. The results reveal that treatment with $30 \mathrm{ng} / \mathrm{mL}$ activin $A$ for 30 and 60 min significantly increased the abundance of the phosphorylated forms of the SMAD2 and SMAD3 proteins (Fig. 4A and B).
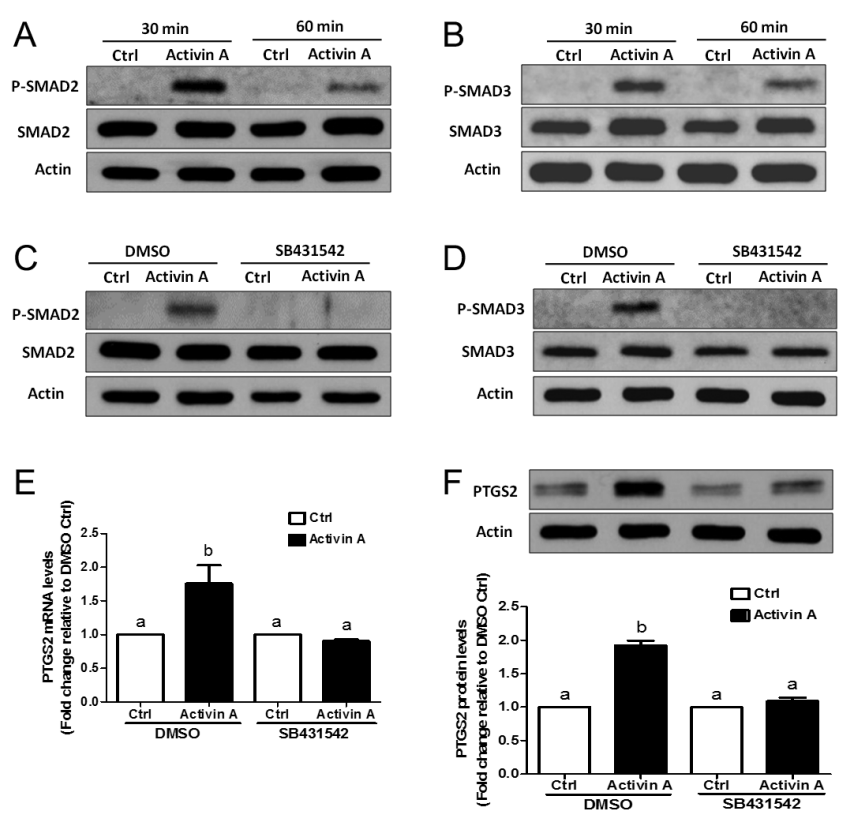

Figure 4 Effects of a TGF- $\beta$ /activin type I receptor inhibitor (SB431542) on the activin A-induced increases in phosphorylated SMAD2/3 levels and the upregulation of PTGS2 expression in SVOG cells. (A and B) SVOG cells were treated with $30 \mathrm{ng} / \mathrm{mL}$ of activin A for $30 \mathrm{~min}$ or $60 \mathrm{~min}$, and the levels of phosphorylated SMAD2 (A) and SMAD3 (B) were examined via western blot analysis. (C and D) SVOG cells were treated with $30 \mathrm{ng} / \mathrm{mL}$ activin $\mathrm{A}$ for $1 \mathrm{~h}$ in the absence (DMSO) or presence of $5 \mu \mathrm{M} \mathrm{SB} 431542$ (an inhibitor of the TGF- $\beta$ type I receptor), and phosphorylated SMAD2 (C) and SMAD3 (D) levels were examined via western blot analysis. (E and F) SVOG cells were treated with $30 \mathrm{ng} / \mathrm{mL}$ activin $A$ for $3 \mathrm{~h}$ or $6 \mathrm{~h}$ in the absence (DMSO) or presence of $5 \mu \mathrm{M}$ SB431542 and the levels of PTGS2 mRNA ( $3 \mathrm{~h}$ ) and protein ( $6 \mathrm{~h}$ ) were examined via RT-qPCR and western blot analysis, respectively. The results are expressed as the mean \pm S.E.M. of at least three independent experiments. Values marked with different letters are significantly different $(P<0.05)$. Ctrl, control. 
TGF- $\beta$ type I receptor is required for the activin A-induced phosphorylation of SMAD2/3 and the upregulation of PTGS2 expression

Activin A initiates a signal transduction pathway by binding to transmembrane serine/threonine receptors (TGF- $\beta$ type II and type I receptors) (Miyazawa et al. 2002). SB431542 is a potent and specific inhibitor of TGF- $\beta$ type I activin receptor-like kinase receptors (Inman et al. 2002). To investigate the involvement of TGF- $\beta$ type I receptors in activin A-induced cellular functions, we pre-treated SVOG cells with SB431542 for $60 \mathrm{~min}$ before adding activin $\mathrm{A}$. As shown in Fig. $4 \mathrm{C}$ and $\mathrm{D}$, the activin A-induced increases in phosphorylated SMAD2 (Fig. 4C) and SMAD3 (Fig. 4D) levels were entirely abolished by the pre-treatment of SVOG cells with $5 \mu \mathrm{M}$ SB431542. Notably, the pretreatment of SVOG cells with $5 \mu \mathrm{M}$ SB431542 also totally abolished the activin A-induced upregulation of PTGS2 mRNA (Fig. 4E) and protein (Fig. 4F) expression.

\section{ACVR1B is required for the activin A-induced increases in phosphorylated SMAD2/3 and the upregulation of PTGS2 expression in SVOG cells}

To further investigate which TGF- $\beta$ type I receptor mediate activin A-induced intracellular actions, specific targeted siRNAs were used to knock down endogenous ACVR1 or ACVR1B expression in SVOG cells. The knockdown efficiency was first confirmed via RT-qPCR to show that the targeted mRNAs were attenuated by the transfection of the specific siRNAs (Fig. 5A and B). Notably, only the knockdown of ACVR1B abolished the activin A-induced increases in phosphorylated SMAD2/3 levels, whereas the knockdown of ACVR1 had no effect (Fig. 5C and D). Similarly, only the knockdown of ACVR1B abolished the activin A-induced upregulation of PTGS2 expression (mRNA and protein), whereas the knockdown of ACVR1 had no effect (Fig. 5E and F). These results indicate that the ACVR1B type I receptor is required for the increases in phosphorylated SMAD2/3 levels and the upregulation of PTGS2 expression induced by activin A in SVOG cells.

\section{SMAD2/3-SMAD4 signaling pathways are required for the activin A-induced upregulation of PTGS2 expression in SVOG cells}

After the binding of activin A to TGF- $\beta$ receptors, the receptors are activated to induce the phosphorylation of the receptor-regulatory SMADs (R-SMADs), SMAD2 and SMAD3. Phosphorylated R-SMADs then bind to the co-mediator SMAD (Co-SMAD) SMAD4, which forms a heteromeric complex and translocates into the nucleus for target gene expression (Shi \& Massague 2003). To further investigate the involvement of SMAD2 and/or SMAD3 in the activin A-induced upregulation of PTGS2 expression, we knocked down the downstream mediators SMADs using specific siRNA. The knockdown efficiency of SMAD2 or SMAD3 was confirmed via RT-qPCR (Fig. 6A and B). As shown in Fig. $6 C$ and $D$, the knockdown of either SMAD2 or SMAD3 abolished the activin A-induced upregulation of PTGS2 mRNA and protein expression. To further confirm the role of SMAD signaling in the activin A-induced upregulation of PTGS2 expression, SVOG cells were treated with activin A after the knockdown of the Co-SMAD SMAD4 (knockdown efficiency was confirmed via RT-qPCR and western blot analysis, Fig. 6E and F). Notably, the knockdown of SMAD4 abolished the activin A-induced increases in PTGS2 mRNA (Fig. 6E) and protein (Fig. 6F) expression in SVOG cells.
A
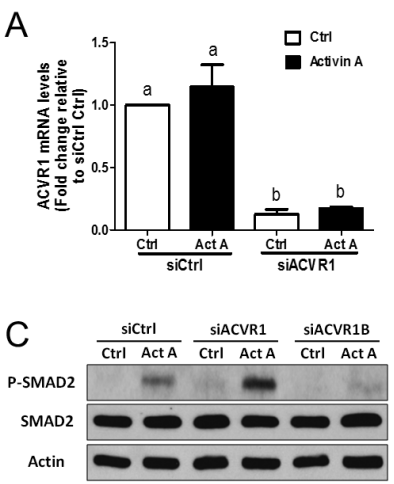

E

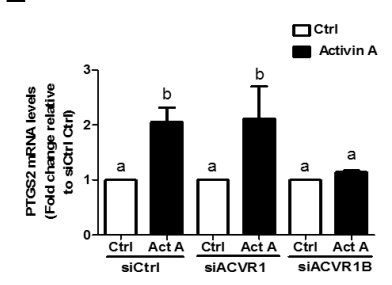

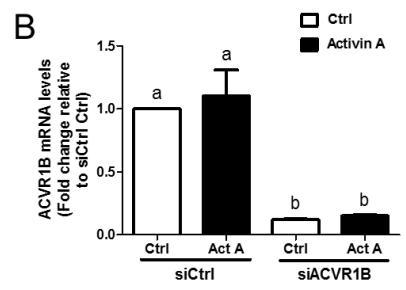
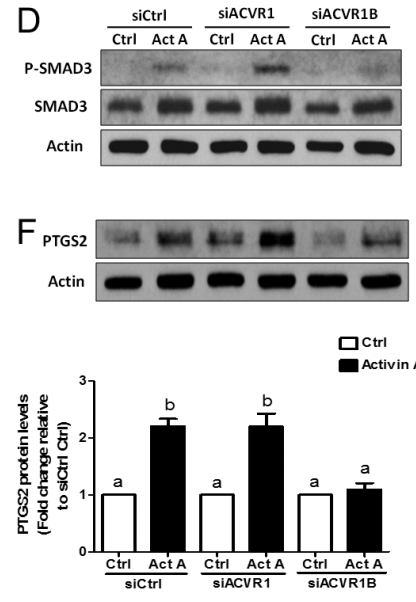

Figure 5 ACVR1B mediates the stimulatory effects of activin A on SMAD2/3 phosphorylation and PTGS2 expression in SVOG cells. (A) Cells were transfected with $25 \mathrm{nM}$ siCtrl or siACVR1 for $48 \mathrm{~h}$, and then treated with $30 \mathrm{ng} / \mathrm{mL}$ activin A. The ACVR1 mRNA levels were examined via RT-qPCR. (B) Cells were transfected with $25 \mathrm{nM}$ siCtrl or siACVR1B for $48 \mathrm{~h}$ and then treated with $30 \mathrm{ng} / \mathrm{mL}$ activin A. The ACVR1B mRNA levels were examined via RT-qPCR. (C and D) Cells were transfected with $25 \mathrm{nM}$ siCtrl, siACVR1 or siACVR1B for $48 \mathrm{~h}$ and then treated with $30 \mathrm{ng} / \mathrm{mL}$ activin $\mathrm{A}$ for $1 \mathrm{~h}$. The levels of phosphorylated SMAD2 (C) and SMAD3 (D) were examined via western blot analysis. (E and F) Cells were transfected with $25 \mathrm{nM}$ siCtrl, siACVR1 or siACVR1B for $48 \mathrm{~h}$ and then treated with $30 \mathrm{ng} / \mathrm{mL}$ activin A for $3 \mathrm{~h}(\mathrm{E})$ or $6 \mathrm{~h}(\mathrm{~F})$. The levels of PTGS2 mRNA (E) and protein $(F)$ were examined via RT-qPCR and western blot analysis, respectively. The results are expressed as the mean \pm S.E.M. of at least three independent experiments. Values marked with different letters are significantly different $(P<0.05)$. Ctrl, control. 
A

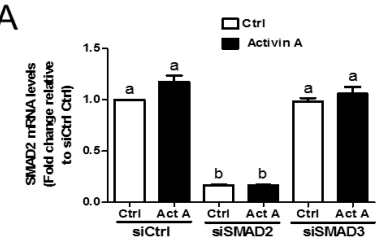

C
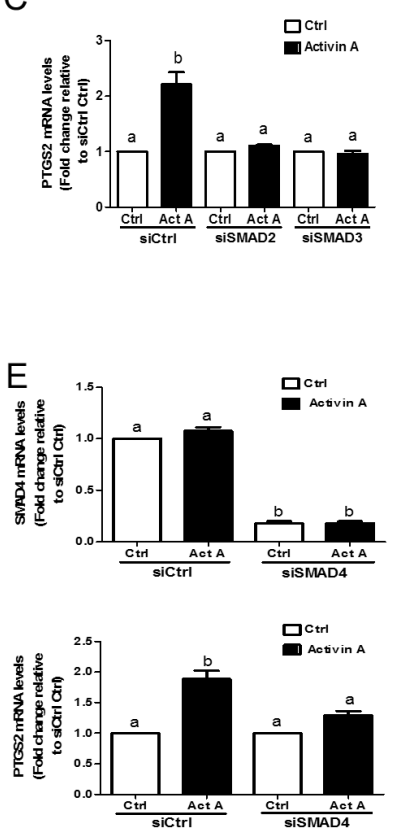

B

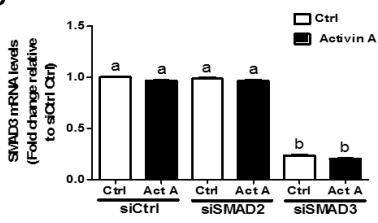

D

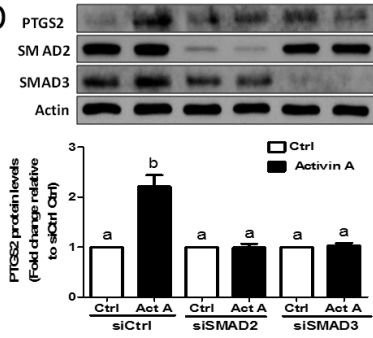

$\mathrm{F}$
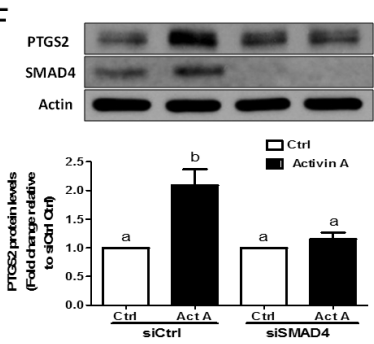

Figure 6 The SMAD2/3-SMAD4 signaling pathway is required for the activin A-induced upregulation of PTGS2 expression in SVOG cells. (A and B) Cells were transfected with $25 \mathrm{nM}$ siCtrl, siSMAD2 or siSMAD3 for $48 \mathrm{~h}$, and the mRNA levels of SMAD2 (A) or SMAD3 (B) were examined via RT-qPCR. (C and D) SVOG cells were transfected with a $25 \mathrm{nM}$ siCtrl, siSMAD2, or siSMAD3 for $48 \mathrm{~h}$ and then treated with $30 \mathrm{ng} / \mathrm{mL}$ of activin A for $3 \mathrm{~h}(\mathrm{C})$ or $6 \mathrm{~h}(\mathrm{D})$. The levels of PTGS2 mRNA (C) and protein (D) were examined via RT-qPCR and western blot analysis, respectively. (E and F) SVOG cells were transfected with $25 \mathrm{nM}$ siCtrl or siSMAD4 for $48 \mathrm{~h}$ and then treated with $30 \mathrm{ng} / \mathrm{mL}$ activin $\mathrm{A}$ for $3 \mathrm{~h}(\mathrm{E})$ or $6 \mathrm{~h}(\mathrm{~F})$. The levels of PTGS2 mRNA (C) and protein (D) were examined via RT-qPCR and western blot analysis, respectively. The results are expressed as the mean \pm S.E.M. of at least three independent experiments.

Values marked with different letters are significantly different $(P<0.05)$. Ctrl, control.

\section{Activin A increases the production of PGE2 in SVOG cells}

PGE2 is the major product of PTGS enzymes and plays a key role in the regulation of corpus luteum formation (Arosh et al. 2004). To further investigate whether activin A-induced PTGS2 expression contributes to the increase in PGE2 production, we treated SVOG cells with different concentrations $(1,10$ or $100 \mathrm{ng} / \mathrm{mL}$ ) of activin $\mathrm{A}$ for $6 \mathrm{~h}$ and examined the PGE2 concentrations in the culture medium. As shown in Fig. 7A, activin A significantly increased PGE2 levels in a concentrationdependent manner. Moreover, pre-treatment with

A

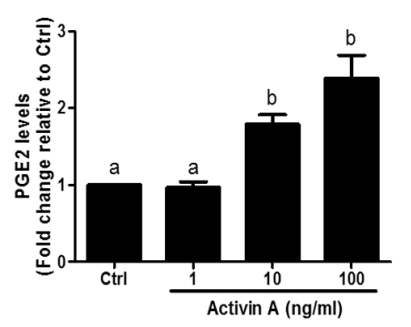

B

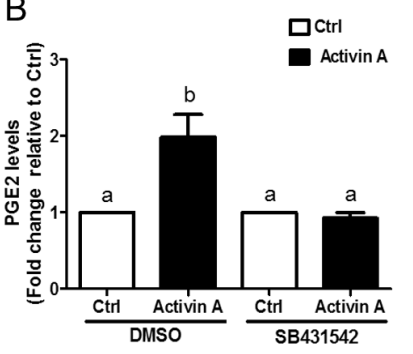

Figure 7 Activin A increases the production of PGE2 in SVOG cells. (A) SVOG cells were treated with vehicle control or different concentrations (1, 10 or $100 \mathrm{ng} / \mathrm{mL}$ ) of activin A for $6 \mathrm{~h}$, and the levels of PGE2 in the medium were examined via ELISA. (B) SVOG cells were treated $30 \mathrm{ng} / \mathrm{mL}$ of activin $\mathrm{A}$ in in the absence (DMSO) or presence of SB431542 $(5 \mu \mathrm{M})$ for $6 \mathrm{~h}$, and the levels of PGE2 in the medium were examined via ELISA. The results are expressed as the mean \pm S.E.M. of at least three independent experiments. Value marked with different letters are significantly different $(P<0.05)$. Ctrl, control.

SB431542 entirely abolished the activin A-induced increase in PGE2 levels in SVOG cells (Fig. 7B).

\section{Discussion}

Locally produced activins have been shown to play a critical role in regulating various ovarian functions, such as folliculogenesis, steroidogenesis and oocyte maturation (Ethier \& Findlay 2001, Knight \& Glister 2001). Increasing evidence has suggested that activin/ inhibin system continues to modulate luteal activity after ovulation (Myers et al. 2007, Knight et al. 2012). In primate corpus luteum, the transcripts of INHA and INHBA, but not of INHBB remain highly expressed during luteal phase (Fraser et al. 1993). Notably, the human corpus luteum has been shown to be the major source of inhibin A or activin A during the mid-luteal stage (Muttukrishna et al. 1994). Indeed, inhibin A has been shown to positively regulate progesterone production in marmoset luteal cells (Webley et al. 1994). Conversely, previous studies have demonstrated the role of activin $\mathrm{A}$ in delaying luteinization because of its ability to inhibit basal, LH/hCG or forskolininduced progesterone production by rat and human granulosa-lutein cells (Miro et al. 1991, Myers et al. 2008, Chang et al. 2014a). In vitro studies in human granulosa-lutein cells have suggested that activin A may also promote tissue remodeling and induce luteolysis during luteal regression (Myers et al. 2007). Furthermore, conditioned knockout of INHBA and INHBB in mice leads to a phenotype of progressive accumulation of corpus luteum and elevated serum progesterone, indicating a functional role of activin in the luteal regression (Pangas et al. 2007). Nonetheless, the present study demonstrated for the first time that activin A could upregulate the expression of PTGS2, which in turn induces the production of PGE2, indicating that activin A may be involved in the corpus 
luteum development and maintenance. A previous in vitro study has shown that activin A promotes the proliferation of luteinized granulosa cells in humans (Rabinovici et al. 1990). The luteinized granulosa cells finally develop into large luteal cells that combined with small luteal cells (derived from luteinized theca cells) to give rise to two distinct types of luteal cells (Weber et al. 1987, Friden et al. 1999). The activin A-induced increase in PGE2 production further stimulates the progesterone secretion in luteal cells, which supports the normal corpus luteum function (Marsh \& LeMaire 1974, Hahlin et al. 1988). Apart from the pituitary gland-derived $\mathrm{LH}$, there is increasing evidence that different growth factors or chemicals can regulate the process of luteinization through various intra-ovarian signaling pathways. It has been reported by our group that EGF-like growth factors (amphiregulin, betacellulin and epiregulin), TGF- $\beta 1$, and nitric oxide can upregulate PTGS2 expression and PGE2 production in hGL cells (Fang et al. 2013, 2014, 2015). In this regard, all of these intra-ovarian factors might work together or interact with each other to upregulate the PTGS2 expression and increase the PGE2 secretion to achieve the goal of luteal phase support. In the present study, we did not demonstrate a role of activin A in the regulation of PTGS1 expression in hGL cells. Currently, the understanding of PTGS1 expression in the regulation of luteal function is limited, and the unveiling of its role will be a major goal in future studies.

To clearly understand the functions and underline mechanisms of the ovarian physiology, materials that are suitable for in vitro studies are required. During the terminal stage of folliculogenesis, granulosa cells proliferate and undergo differentiation and luteinization. In the present study, immortalized SVOG cells and primary hGL cells obtained from IVF patients (Lie et al. 1996) were used as cell models. These clinically obtained hGL cells are normally luteinized because of their stimulation of high dose of human chorionic gonadotropin (hCG) before cell isolation, which provides an attractive model for studying the related luteal function, especially the early luteal development.

In this study, we have showed that activin A induces the upregulation of PTGS2 expression and PGE2 production via an ACVR1B-mediated SMAD2/3SMAD4-dependent pathway in human granulosa-lutein cells. It has been reported that the selective knockout of SMAD4 in the ovaries of mice results in multiple defects in folliculogenesis, decreasing fertility and premature ovarian failure (Pangas et al. 2006, Yu et al. 2013). In this study, our results show that the knockdown of SMAD4 abolishes the activin A-induced increase in PTGS2 expression in SVOG cells. According to the animal studies mentioned above and the results of our study, the SMAD signaling pathway plays an important role in the regulation of luteal function. Our data reveal that activin
A induces PTGS2 expression by activating the SMAD2/3 pathway in hGL cells. The knockdown of SMAD2 or SMAD3 abrogated the activin A-induced increase in PTGS2 expression. Our results demonstrate that both SMAD2 and SMAD3 are involved in mediating activin A-induced PTGS2 expression, which is consistent with a previous report by our group showing that TGF- $\beta 1$ upregulates PTGS2 expression via both the SMAD2 and SMAD3 signaling pathways (Fang et al. 2014). However, inconsistent with this study, one of our previous studies showed that only SMAD2 but not SMAD3 signaling mediates the activin A-induced downregulation of StAR expression in the SVOG cells (Chang et al. 2015b). Studies in knockout mice comparing the phenotypes of target deletion of either SMAD2 or SMAD3 suggested that two SMADs may have distinct roles in the mediation of TGF- $\beta$ /activin ligands (Piek et al. 2001). Specifically, the activin A-induced specific responses being mediated by SMAD2 or SMAD3 are target gene-dependent. In addition to the canonical SMAD pathway, other nonSMAD signaling cascades, such as ERK $1 / 2$, can also mediate PTGS2 expression for the members of the TGF- $\beta$ superfamily. In a previous animal study, ovarian failure and infertility were found in ERK1/2-deficient female mice (Fan et al. 2009). It has also been reported that human chorionic gonadotropin-induced PTGS2 expression and PGE2 production are attenuated by the inhibition of the ERK1/2 signaling pathway in hGL cells (Tsai et al. 2008). Previously, our group reported that EGF-like growth factors upregulated PTGS2 expression and PGE2 production through the ERK1/2 signaling pathway in hGL cells (Fang et al. 2013). In addition, we have demonstrated that nitric oxide may induce PTGS2 expression and PGE2 production by activating the CREB signaling pathway in the same cell model (Fang et al. 2015). All of these data suggest that PTGS2 expression and PGE2 production can be induced by non-SMAD signaling pathways. However, as shown in the present study, non-SMAD signaling pathways are not involved in the activin A-induced changes in PTGS2 expression and PGE2 production in hGL cells. Taken together, previous studies and our data increase our understanding of the role of activin $\mathrm{A}$ in regulating luteal function and might benefit to develop a pharmaceutical strategy for luteal dysfunction, implantation failure and early pregnancy loss.

In summary, this study indicates that activin A upregulates PTGS2 expression and PGE2 production in hGL cells. In addition, treatment with activin A activates the ACVR1B-mediated SMAD2/3 and SMAD4 signaling pathways. Furthermore, the inhibition of the type I receptor abolishes the activin A-induced increase in PTGS2 expression and PGE2 production. Our results suggest that activin A may play a critical role in the modulation of the human corpus luteum formation and maintenance via the induction of PTGS2 expression and PGE2 secretion. 


\section{Declaration of interest}

The authors declare that there is no conflict of interest that could be perceived as prejudicing the impartiality of the research reported.

\section{Funding}

This research was supported by an operating grant (\#143317) from the Canadian Institutes of Health Research to P C K L.

\section{Acknowledgements}

We thank Dr Elizabeth L Taylor for coordinating the acquisition of patient follicular fluid samples.

\section{References}

Arosh JA, Banu SK, Chapdelaine P, Madore E, Sirois J \& Fortier MA 2004 Prostaglandin biosynthesis, transport, and signaling in corpus luteum: a basis for autoregulation of luteal function. Endocrinology 145 2551-2560. (doi:10.1210/en.2003-1607)

Bogan RL, Murphy MJ, Stouffer RL \& Hennebold JD 2008 Prostaglandin synthesis, metabolism, and signaling potential in the rhesus macaque corpus luteum throughout the luteal phase of the menstrual cycle. Endocrinology 149 5861-5871. (doi:10.1210/en.2008-0500)

Chang HM, Cheng JC, Fang L, Qiu X, Klausen C, Taylor EL \& Leung PC 2015a Recombinant BMP4 and BMP7 downregulate pentraxin 3 in human granulosa cells. Journal of Clinical Endocrinology and Metabolism 100 E365-E374. (doi:10.1210/jc.2014-2496)

Chang HM, Cheng JC, Huang HF, Shi FT \& Leung PC 2015b Activin A, $B$ and $A B$ decrease progesterone production by down-regulating StAR in human granulosa cells. Molecular and Cellular Endocrinology 412 290-301. (doi:10.1016/j.mce.2015.05.016)

Chang HM, Cheng JC, Klausen C \& Leung PC 2015c Recombinant BMP4 and BMP7 increase activin A production by up-regulating inhibin betaA subunit and furin expression in human granulosa-lutein cells. Journal of Clinical Endocrinology and Metabolism 100 E375-E386. (doi:10.1210/ jc.2014-3026)

Chang HM, Cheng JC, Klausen C, Taylor EL \& Leung PC 2014 a Effects of recombinant activins on steroidogenesis in human granulosalutein cells. Journal of Clinical Endocrinology and Metabolism 99 E1922-E1932. (doi:10.1210/jc.2014-1223)

Chang HM, Cheng JC, Taylor E \& Leung PC 2014b Oocyte-derived BMP15 but not GDF9 down-regulates connexin43 expression and decreases gap junction intercellular communication activity in immortalized human granulosa cells. Molecular Human Reproduction 20 373-383. (doi:10.1093/molehr/gau001)

Chang HM, Fang L, Cheng JC, Taylor EL, Sun YP \& Leung PC $2016 \mathrm{a}$ Effects of growth differentiation factor 8 on steroidogenesis in human granulosa-lutein cells. Fertility and Sterility 105 520-528. (doi:10.1016/j. fertnstert.2015.10.034)

Chang HM, Pan HH, Cheng JC, Zhu YM \& Leung PC 2016 b Growth differentiation factor 8 suppresses cell proliferation by up-regulating CTGF expression in human granulosa cells. Molecular and Cellular Endocrinology 422 9-17. (doi:10.1016/j.mce.2015.11.009)

Chen YC, Chang HM, Cheng JC, Tsai HD, Wu CH \& Leung PC 2015 Transforming growth factor-beta1 up-regulates connexin43 expression in human granulosa cells. Human Reproduction 30 2190-2201. (doi:10.1093/humrep/dev175)

Derynck R \& Zhang YE 2003 Smad-dependent and Smad-independent pathways in TGF-beta family signalling. Nature 425 577-584. (doi:10.1038/nature02006)

Devoto L, Kohen P, Munoz A \& Strauss JF 3rd 2009 Human corpus luteum physiology and the luteal-phase dysfunction associated with ovarian stimulation. Reproductive Biomedicine Online 18 (Supplement 2) 19-24. (doi:10.1016/S1472-6483(10)60444-0)
Edelman AB, Jensen JT \& Hennebold JD 2010 A nonhormonal model for emergency contraception: prostaglandin synthesis inhibitor effects on luteal function and lifespan, a pilot study. Contraception 81 496-500. (doi:10.1016/j.contraception.2010.01.004)

Eramaa M, Heikinheimo K, Tuuri T, Hilden K \& Ritvos O 1993 Inhibin/ activin subunit mRNA expression in human granulosa-luteal cells. Molecular and Cellular Endocrinology 92 R15-R20. (doi:10.1016/03037207(93)90020-K)

Ethier JF \& Findlay JK 2001 Roles of activin and its signal transduction mechanisms in reproductive tissues. Reproduction 121 667-675. (doi:10.1530/rep.0.1210667)

Fan HY, Liu Z, Shimada M, Sterneck E, Johnson PF, Hedrick SM \& Richards JS 2009 MAPK3/1 (ERK1/2) in ovarian granulosa cells are essential for female fertility. Science 324 938-941. (doi:10.1126/ science.1171396)

Fang L, Chang HM, Cheng JC, Leung PC \& Sun YP 2014 TGF-beta1 induces COX-2 expression and PGE2 production in human granulosa cells through Smad signaling pathways. Journal of Clinical Endocrinology and Metabolism 99 E1217-E1226. (doi:10.1210/jc.2013-4100)

Fang L, Chang HM, Cheng JC, Leung PC \& Sun YP 2015 Nitric oxide and CGMP induce COX-2 expression and PGE2 production in human granulosa cells through CREB signaling pathway. Journal of Clinical Endocrinology and Metabolism 100 E262-E269. (doi:10.1210/jc.2014-2886)

Fang L, Cheng JC, Chang HM, Sun YP \& Leung PC 2013 EGF-like growth factors induce COX-2-derived PGE2 production through ERK1/2 in human granulosa cells. Journal of Clinical Endocrinology and Metabolism 98 4932-4941. (doi:10.1210/jc.2013-2662)

Findlay JK 1993 An update on the roles of inhibin, activin, and follistatin as local regulators of folliculogenesis. Biology of Reproduction 48 15-23. (doi:10.1095/biolreprod48.1.15)

Fraser HM, Lunn SF, Cowen GM \& Saunders PT 1993 Localization of inhibin/activin subunit mRNAs during the luteal phase in the primate ovary. Journal of Molecular Endocrinology 10 245-257. (doi:10.1677/ jme.0.0100245)

Friden BE, Hagstrom $\mathbf{H}$, Lindblom B, Sjoblom $\mathbf{P}$, Wallin A, Brannstrom $M$ \& Hahlin M 1999 Cell characteristics and function of two enriched fraction of human luteal cells prolonged culture. Molecular Human Reproduction 5 714-719. (doi:10.1093/molehr/5.8.714)

Hahlin M, Dennefors B, Johanson C \& Hamberger L 1988 Luteotropic effects of prostaglandin E2 on the human corpus luteum of the menstrual cycle and early pregnancy. Journal of Clinical Endocrinology and Metabolism 66 909-914. (doi:10.1210/jcem-66-5-909)

Henderson KM, Scaramuzzi RJ \& Baird DT 1977 Simultaneous infusion of prostaglandin E2 antagonizes the luteolytic action of prostaglandin F2alpha in vivo. Journal of Endocrinology 72 379-383. (doi:10.1677/ joe.0.0720379)

Horton EW \& Poyser NL 1976 Uterine luteolytic hormone: a physiological role for prostaglandin F2alpha. Physiological Reviews 56 595-651.

Inman GJ, Nicolas FJ, Callahan JF, Harling JD, Gaster LM, Reith AD, Laping NJ \& Hill CS 2002 SB-431542 is a potent and specific inhibitor of transforming growth factor-beta superfamily type I activin receptor-like kinase (ALK) receptors ALK4, ALK5, and ALK7. Molecular Pharmacology 62 65-74. (doi:10.1124/mol.62.1.65)

Kim L, Weems YS, Bridges PJ, LeaMaster BR, Ching L, Vincent DL \& Weems CW 2001 Effects of indomethacin, luteinizing hormone (LH), prostaglandin E2 (PGE2), trilostane, mifepristone, ethamoxytriphetol (MER-25) on secretion of prostaglandin E (PGE), prostaglandin F2alpha (PGF2alpha) and progesterone by ovine corpora lutea of pregnancy or the estrous cycle. Prostaglandins and Other Lipid Mediators 63 189-203. (doi:10.1016/S0090-6980(01)00097-1)

Knight PG \& Glister C 2001 Potential local regulatory functions of inhibins, activins and follistatin in the ovary. Reproduction $121503-512$. (doi:10.1530/rep.0.1210503)

Knight PG \& Glister C 2006 TGF-beta superfamily members and ovarian follicle development. Reproduction 132 191-206. (doi:10.1530/ rep.1.01074)

Knight PG, Satchell L \& Glister C 2012 Intra-ovarian roles of activins and inhibins. Molecular and Cellular Endocrinology 359 53-65. (doi:10.1016/j.mce.2011.04.024)

Lie BL, Leung E, Leung PC \& Auersperg N 1996 Long-term growth and steroidogenic potential of human granulosa-lutein cells immortalized with SV40 large T antigen. Molecular and Cellular Endocrinology 120 169-176. (doi:10.1016/0303-7207(96)03835-X) 
Lim H, Gupta RA, Ma WG, Paria BC, Moller DE, Morrow JD, DuBois RN, Trzaskos JM \& Dey SK 1999 Cyclo-oxygenase-2-derived prostacyclin mediates embryo implantation in the mouse via PPARdelta. Genes and Development 13 1561-1574. (doi:10.1101/gad.13.12.1561)

Liu B, Qu L \& Yan S 2015 Cyclooxygenase-2 promotes tumor growth and suppresses tumor immunity. Cancer Cell International 15106. (doi:10.1186/s12935-015-0260-7)

Magness RR, Huie JM, Hoyer GL, Huecksteadt TP, Reynolds LP, Seperich GJ, Whysong G \& Weems CW 1981 Effect of chronic ipsilateral or contralateral intrauterine infusion of prostaglandin E2 (PGE2) on luteal function of unilaterally ovariectomized ewes. Prostaglandins and Medicine 6 389-401. (doi:10.1016/0161-4630(81)90071-9)

Marsh JM \& LeMaire WJ 1974 Cyclic AMP accumulation and steroidogenesis in the human corpus luteum: effect of gonadotropins and prostaglandins. Journal of Clinical Endocrinology and Metabolism 38 99-106. (doi:10.1210/jcem-38-1-99)

Miro F, Smyth CD \& Hillier SG 1991 Development-related effects of recombinant activin on steroid synthesis in rat granulosa cells. Endocrinology 129 3388-3394. (doi:10.1210/endo-129-6-3388)

Miyazawa K, Shinozaki M, Hara T, Furuya T \& Miyazono K 2002 Two major Smad pathways in TGF-beta superfamily signalling. Genes to Cells 7 1191-1204. (doi:10.1046/j.1365-2443.2002.00599.x)

Muttukrishna S, Fowler PA, Groome NP, Mitchell GG, Robertson WR \& Knight PG 1994 Serum concentrations of dimeric inhibin during the spontaneous human menstrual cycle and after treatment with exogenous gonadotrophin. Human Reproduction 9 1634-1642.

Myers M, Gay E, McNeilly AS, Fraser HM \& Duncan WC 2007 In vitro evidence suggests activin-A may promote tissue remodeling associated with human luteolysis. Endocrinology 148 3730-3739. (doi:10.1210/ en.2007-0244)

Myers M, van den Driesche S, McNeilly AS \& Duncan WC 2008 Activin A reduces luteinisation of human luteinised granulosa cells and has opposing effects to human chorionic gonadotropin in vitro. Journal of Endocrinology 199 201-212. (doi:10.1677/JOE-08-0302)

Niswender GD, Juengel JL, Silva PJ, Rollyson MK \& McIntush EW 2000 Mechanisms controlling the function and life span of the corpus luteum. Physiological Reviews 80 1-29.

Pangas SA, Jorgez CJ, Tran M, Agno J, Li X, Brown CW, Kumar TR \& Matzuk MM 2007 Intraovarian activins are required for female fertility. Molecular Endocrinology 21 2458-2471. (doi:10.1210/me.2007-0146)

Pangas SA, Li X, Robertson EJ \& Matzuk MM 2006 Premature luteinization and cumulus cell defects in ovarian-specific Smad4 knockout mice. Molecular Endocrinology 20 1406-1422. (doi:10.1210/me.2005-0462)

Pate JL 2003 Lives in the balance: responsiveness of the corpus luteum to uterine and embryonic signals. Reproduction Supplement 61 207-217.

Piek E, Ju WJ, Heyer J, Escalante-Alcalde D, Stewart CL, Weinstein M, Deng C, Kucherlapati R, Bottinger EP \& Roberts AB 2001 Functional characterization of transforming growth factor beta signaling in Smad2 and Smad3-deficient fibroblasts. Journal of Biological Chemistry 276 19945-19953. (doi:10.1074/jbc.M102382200)

Rabinovici J, Spencer SJ \& Jaffe RB 1990 Recombinant human activin-A promotes proliferation of human luteinized preovulatory granulosa cells in vitro. Journal of Clinical Endocrinology and Metabolism 71 1396-1398. (doi:10.1210/jcem-71-5-1396)

Reese J, Zhao X, Ma WG, Brown N, Maziasz TJ \& Dey SK 2001 Comparative analysis of pharmacologic and/or genetic disruption of cyclooxygenase-1 and cyclooxygenase-2 function in female reproduction in mice. Endocrinology 142 3198-3206. (doi:10.1210/en.142.7.3198)

Roberts VJ, Barth S, el-Roeiy A \& Yen SS 1993 Expression of inhibin/ activin subunits and follistatin messenger ribonucleic acids and proteins in ovarian follicles and the corpus luteum during the human menstrual cycle. Journal of Clinical Endocrinology and Metabolism 77 1402-1410. (doi:10.1210/jc.77.5.1402)

Shi Y \& Massague J 2003 Mechanisms of TGF-beta signaling from cell membrane to the nucleus. Cell 113 685-700. (doi:10.1016/S00928674(03)00432-X)
Silva JR, van den Hurk R, van Tol HT, Roelen BA \& Figueiredo JR 2004 Gene expression and protein localisation for activin-A, follistatin and activin receptors in goat ovaries. Journal of Endocrinology 183 405-415. (doi:10.1677/joe.1.05756)

Sirois J, Sayasith K, Brown KA, Stock AE, Bouchard N \& Dore M 2004 Cyclooxygenase-2 and its role in ovulation: a 2004 account. Human Reproduction Update 10 373-385. (doi:10.1093/humupd/ dmh032)

Stouffer RL, Xu F \& Duffy DM 2007 Molecular control of ovulation and luteinization in the primate follicle. Frontiers in Bioscience 12 297-307. (doi:10.2741/2065)

Tsai EM, Chan TF, Chen YH, Hsu SC, Chuang CY \& Lee JN 2008 Mifepristone attenuates human chorionic gonadotropin-induced extracellular signal-regulated kinase $1 / 2$ phosphorylation, cyclooxygenase-2, and prostaglandin E2 production in human granulosa luteal cells. Fertility and Sterility $\mathbf{8 9}$ 1522-1529. (doi:10.1016/j.fertnstert.2007.05.053)

Vijayakumar R \& Walters WA 1983 Human luteal tissue prostaglandins, 17 beta-estradiol, and progesterone in relation to the growth and senescence of the corpus luteum. Fertility and Sterility 39 298-303. (doi:10.1016/S0015-0282(16)46875-5)

Wang J, Shen XX, Huang XH \& Zhao ZM 2012 Follicular fluid levels of prostaglandin E2 and the effect of prostaglandin E2 on steroidogenesis in granulosa-lutein cells in women with moderate and severe endometriosis undergoing in vitro fertilization and embryo transfer. Chinese Medical Journal 125 3985-3990.

Weber DM, Fields PA, Romrell LJ, Tumwasorn S, Ball BA, Drost M \& Fields MJ 1987 Functional differences between small and large luteal cells of the late-pregnant vs. nonpregnant cow. Biology of Reproduction 37 685-697. (doi:10.1095/biolreprod37.3.685)

Webley GE, Marsden PL \& Knight PG 1994 Differential control of immunoreactive alpha-inhibin and progesterone production by marmoset luteal cells in vitro: evidence for a paracrine action of alpha-inhibin on basal and gonadotropin-stimulated progesterone production. Biology of Reproduction 50 1394-1402. (doi:10.1095/ biolreprod50.6.1394)

Weems YS, Raney A, Pang J, Uchima T, Lennon E, Johnson D, Nett TM, Randel RD \& Weems CW 2013 Prostaglandin E1 or E2 (PGE1, PGE2) prevents premature luteolysis induced by progesterone given early in the estrous cycle in ewes. Theriogenology 80 507-512. (doi:10.1016/j. theriogenology.2013.05.014)

Weems YS, Pang J, Raney A, Uchima T, Lennon E, Johnson D, Nett TM, Randel RD \& Weems CW 2014 Prostaglandin E1 or E2 inhibits an oxytocin-induced premature luteolysis in ewes when oxytocin is given early in the estrous cycle. Theriogenology 82 440-446. (doi:10.1016/j. theriogenology.2014.04.024)

Woodruff TK, D'Agostino J, Schwartz NB \& Mayo KE 1988 Dynamic changes in inhibin messenger RNAs in rat ovarian follicles during the reproductive cycle. Science 239 1296-1299. (doi:10.1126/ science.3125611)

Yu C, Zhang YL \& Fan HY 2013 Selective Smad4 knockout in ovarian preovulatory follicles results in multiple defects in ovulation. Molecular Endocrinology 27 966-978. (doi:10.1210/me.2012-1364)

Zelinski-Wooten MB \& Stouffer RL 1990 Intraluteal infusions of prostaglandins of the E, D, I, and A series prevent PGF2 alpha-induced, but not spontaneous, luteal regression in rhesus monkeys. Biology of Reproduction 43 507-516. (doi:10.1095/biolreprod43.3.507)

Received 9 May 2016

First decision 5 June 2016

Revised manuscript received 7 September 2016

Accepted 13 September 2016 